\title{
Corrosion Inhibition of Electrodeposited Tellurium and Palladium in Nitric Acid Solution
}

\author{
A.S. Fouda, ${ }^{*}$ H.A. Mostafa, M.N. Moussa \\ Chemistry Department, Faculty of Science, El-Mansoura University, \\ El-Mansoura-35516, Egypt
}

Received 23 February 2004; accepted in revised form 5 January 2005

\begin{abstract}
Corrosion inhibition of 3-phenyl hydrazonoacetyl acetone derivatives on electrodeposited tellurium and palladium in nitric acid was measured by using electrochemical method. Polarization curves showed that these compounds are cathodic inhibitors. The inhibition appears to function through general adsorption following the Flory-Huggins adsorption isotherm. The rate of corrosion depends on the nature of the inhibitor and its concentration, mode of interaction with the metal surface, molecular size, formation of complexes and the active center in the molecules and its electron charge density. Also, $\Delta \mathrm{G}_{\text {ads. }}^{\mathrm{o}}$ values were calculated. The reaction rate was found to be proportional to the absolute value of the Hammett constant $(\sigma)$.
\end{abstract}

Keywords: tellurium, palladium, corrosion inhibition, phenyl hydrazonoacetyl acetone, nitric acid.

\section{Introduction}

Acid solutions are generally used for the removal of undesirable scale and rust in several industrial processes. Inhibitors are generally used in these processes to control the metal dissolution as well as acid consumption. Most of the well known acid inhibitors are organic compounds containing nitrogen, oxygen and/or sulphur atoms. Moreover, many N-heterocyclic compounds have been proved to be effective inhibitors for the corrosion of metals and alloys in aqueous media [1-

\footnotetext{
* Corresponding author. E-mail address: asfouda@yahoo.com
} 
2]. The influence of organic compounds containing nitrogen, oxygen and/or sulphur on the corrosion of metals in aqueous media has been investigated by several authors [3-9]. These organic compounds can adsorb on the metal surface, block the active sites on the surface and thereby reduce the corrosion rate.

This paper describes a study of the protection efficiency of phenyl hydrazonoacetyl acetone derivatives for tellurium and palladium corrosion in acid solution. The behaviour of these compounds in $0.5 \mathrm{M} \mathrm{HNO}_{3}$ has been investigated and their protection efficiency has been determined by galvanostatic polarization method.

I) p-methoxy-3-phenyl hydrazonoacetyl acetone<smiles>COc1ccc(N/N=C(\C)C(C)=O)cc1</smiles>

II) p-chloro-3-phenyl hydrazonoacetyl acetone<smiles>CC(=O)C(=NNc1ccc(Cl)cc1)C(C)=O</smiles>

III) p-methyl-3-phenyl hydrazonoacetyl acetone<smiles>CC(=O)C(=NNc1ccc(C)cc1)C(C)=O</smiles>

IV) p-phenyl hydrazonoacetyl acetone<smiles>CC(=O)C(=NNc1ccccc1)C(C)=O</smiles> 
V) p-hydroxy-3-phenyl hydrazonoacetyl acetone<smiles>CC(=O)C(=NNc1ccc(O)cc1)C(C)=O</smiles>

\section{Experimental details}

Experiments were carried out in $0.5 \mathrm{M} \mathrm{HNO}_{3}$ solution in the presence of different concentrations of substituted phenyl hydrazonoacetyl acetone solutions. These compounds were prepared, purified, and kept as described before [10]. All solutions were prepared from doubly distilled water and A.R. chemicals. New electrodes were used for each run. The working electrodes were prepared by electrodeposition from phthalic acid [11] and potassium dihydrogen phosphate [12] baths for tellurium and palladium, respectively, on a platinum sheet cathode. A platinum sheet was used as the counter electrode. The potential was measured against SCE reference electrode. The influence of inhibitors on the corrosion of tellurium and palladium in $0.5 \mathrm{~N} \mathrm{HNO}_{3}$ was monitored electrochemically. For the polarization study, a standard corrosion cell with a working tellurium or palladium electrode of area $1.8 \mathrm{~cm}^{2}$ was used. The galvanostatic measurements were ran on a potentiostat-galvanostat (AMEL model 591).

Bath for tellurium electrodeposition: $\mathrm{Te}(\mathrm{OH})_{6} 0.1 \mathrm{M}$, phthalic acid $0.05 \mathrm{M}, \mathrm{KCl}$ $0.025 \mathrm{M}$, current density $1.1 \mathrm{~mA} \mathrm{~cm}^{-2}$, time $=60 \mathrm{~min}$ and at $25^{\circ} \mathrm{C}$.

Bath for palladium electrodeposition: $\mathrm{PdCl}_{3} 1.0 \mathrm{M}, \mathrm{KH}_{2} \mathrm{PO}_{4} 0.15 \mathrm{M}, \mathrm{pH}=1.5$, current density $0.85 \mu \mathrm{A} \mathrm{cm}^{-2}$, time $=60 \mathrm{~min}$ and at $25^{\circ} \mathrm{C}$.

\section{Results and discussion}

The results of the cathodic polarization of the electrodeposited tellurium [11] and palladium [12] in the presence and absence of different concentrations of compound (I) are plotted in Figs. 1 and 2. 


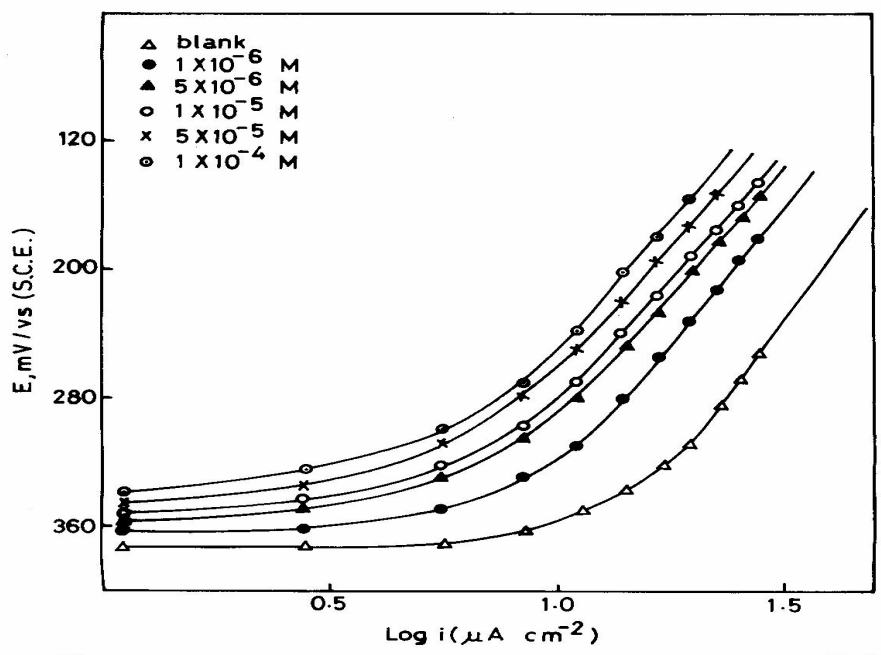

Figure 1. Effect of the concentration of p-methoxy-3-phenyl hydrazonoacetyl-acetone on the cathodic Te reaction in $0.5 \mathrm{M} \mathrm{HNO}_{3}$ at $25^{\circ} \mathrm{C}$.

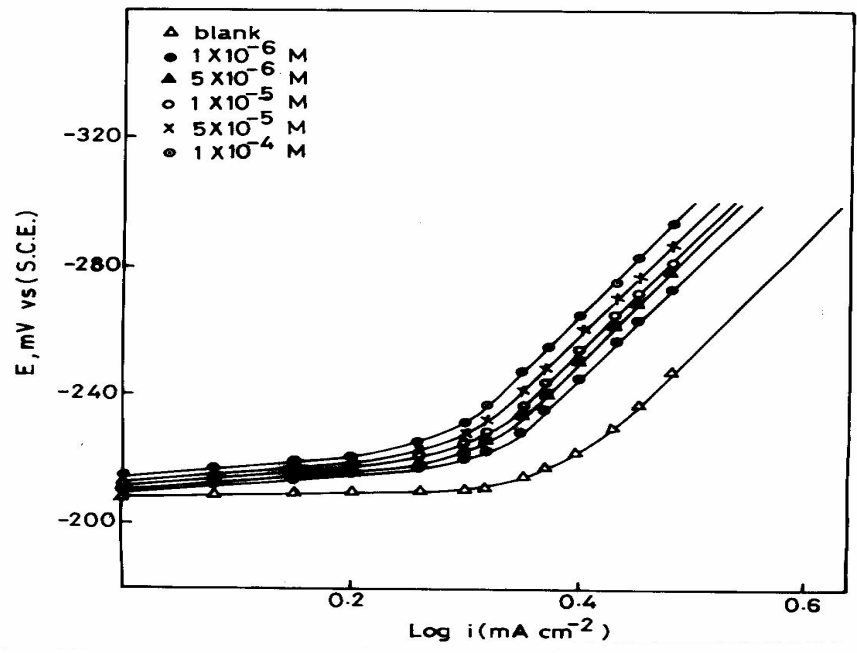

Figure 2. Effect of the concentration of p-methoxy-3-phenyl hydrazonoacetylacetone on the cathodic $\mathrm{Pd}$ reaction in $0.5 \mathrm{M} \mathrm{HNO}_{3}$ at $25^{\circ} \mathrm{C}$.

In case of cathodic polarization, the results show that as the concentration of the inhibitor increases the Tafel lines are shifted to more negative potentials relative to the blank curve, but in case of anodic polarization, the curves in presence of inhibitors lie on that of the free acid. This indicates that these inhibitors affect only the cathodic polarization and act only as cathodic inhibitors. The free corrosion potentials are affected slightly and the Tafel slopes are nearly constant 
and ranging from -354 to $-372 \mathrm{mV}$ decade $^{-1}$ for tellurium and from -197 to -208 $\mathrm{mV}$ decade $^{-1}$ for palladium.

These results suggest that the presence of inhibitors do not affect the mechanism of the corrosion process. Tables 1 and 2 show the effect of inhibitor concentration on free corrosion potential ( $\left.\mathrm{E}_{\text {corr. }}\right)$, corrosion current density ( $\left.\mathrm{i}_{\text {corr. }}\right)$, degree of surface coverage $(\theta)$ and percentage inhibition. The decrease in $i_{\text {corr. }}$ and the increases in both percentage inhibition and degree of surface coverage with increasing the concentration of the inhibitors demonstrate the efficiency of 3-phenyl hydrazonoacetyl acetone derivatives as corrosion inhibitors.

Table 1. The effect of p-methoxy-3-phenyl hydrazonoacetyl acetone concentration on the free corrosion potential, Tafel slope, corrosion current density and its percentage decrease and degree of surface coverage of adsorption for tellurium in $0.5 \mathrm{M} \mathrm{HNO}_{3}$ at $25{ }^{\circ} \mathrm{C}$.

\begin{tabular}{cccccc}
\hline $\begin{array}{c}\text { Concentration } \\
(\mathrm{M})\end{array}$ & $\begin{array}{c}-\mathrm{E}_{\text {corr. }} \\
(\mathrm{mV})\end{array}$ & $\begin{array}{c}\mathrm{b}_{\mathrm{c}} \\
(\mathrm{mV} / \text { currentdec })\end{array}$ & $\begin{array}{c}\mathrm{i}_{\text {corr. }} \\
\left(\mu \mathrm{A} / \mathrm{cm}^{2}\right)\end{array}$ & $\begin{array}{c}\mathrm{P}_{\mathrm{i}_{\text {corr. }}} \\
(\%)\end{array}$ & $\theta$ \\
\hline 0 & 372 & 48.2 & 13.5 & - & - \\
$1 \times 10^{-6}$ & 360 & 47.1 & 8.1 & 39.7 & 0.39 \\
$5 \times 10^{-6}$ & 352 & 44.5 & 6.6 & 51.0 & 0.51 \\
$1 \times 10^{-5}$ & 356 & 48.2 & 6.0 & 55.3 & 0.54 \\
$5 \times 10^{-5}$ & 354 & 45.0 & 5.4 & 60.6 & 0.61 \\
$1 \times 10^{-4}$ & 354 & 45.0 & 4.8 & 64.4 & 0.65 \\
\hline
\end{tabular}

Table 2. The effect of p-methoxy-3-phenyl hydrazonoacetyl acetone on the free corrosion potential, Tafel slope, corrosion current density and its percentage decrease and degree of surface coverage of adsorption of palladium in $0.5 \mathrm{M} \mathrm{HNO}_{3}$ at $25{ }^{\circ} \mathrm{C}$.

\begin{tabular}{cccccc}
\hline $\begin{array}{c}\text { Concentration } \\
(\mathrm{M})\end{array}$ & $\begin{array}{c}-\mathrm{E}_{\text {corr. }} \\
(\mathrm{mV})\end{array}$ & $\begin{array}{c}\mathrm{b}_{\mathrm{c}} \\
(\mathrm{mV} / \text { current dec })\end{array}$ & $\begin{array}{c}\mathrm{i}_{\text {corr. }} \\
\left(\mu \mathrm{A} / \mathrm{cm}^{2}\right)\end{array}$ & $\begin{array}{c}\mathrm{P}_{\mathrm{i}_{\text {corr. }}} \\
(\%)\end{array}$ & $\theta$ \\
\hline 0 & 208 & 30.7 & 2.2 & - & - \\
$1 \times 10^{-6}$ & 200 & 33.0 & 1.8 & 15.8 & 0.16 \\
$5 \times 10^{-6}$ & 200 & 30.8 & 1.8 & 18.7 & 0.19 \\
$1 \times 10^{-5}$ & 199 & 27.4 & 1.7 & 21.0 & 0.21 \\
$5 \times 10^{-5}$ & 197 & 28.1 & 1.7 & 22.8 & 0.23 \\
$1 \times 10^{-4}$ & 199 & 29.5 & 1.6 & 25.9 & 0.26 \\
\hline
\end{tabular}

Assuming no change in the mechanism of both the hydrogen evolution reaction and the electrodissolution of tellurium and palladium, according to Damaskin [13] the formula: 


$$
\theta=1-\frac{\mathrm{i}_{\text {inh. }}}{\mathrm{i}_{\text {uninh. }}}
$$

can be used for the determination of the degree of surface coverage $(\theta)$. Different adsorption isotherms were tested for their fit to the experimental results. The Flory-Huggins adsorption isotherm and the kinetic model [14] fit the obtained experimental data well, with a correlation coefficient greater than unity. The adsorption isotherm relationships of Flory-Huggins and El-Awady model are described by equations (2) and (3)

$$
\begin{aligned}
& \log (\theta / C)=\log K+x \log (1-\theta) \\
& \log (\theta / 1-\theta)=\log K^{\prime}+y \log C
\end{aligned}
$$

where $\mathrm{x}$ is the number of the active sites occupied by one inhibitor molecule (the number of water molecules replaced by one molecule of inhibitor). The number of active sites of the surface occupied by one molecule of inhibitor is also given by the value of $(1 / y) . K$ is the binding constant of the adsorption reaction $(K=$ $\left.\mathrm{K}^{(1 / \mathrm{y})}\right)$. $\mathrm{C}$ is the inhibitor concentration in the bulk of solution. The binding constant of adsorption $\mathrm{K}$ is related to the standard free energy of adsorption $\Delta \mathrm{G}_{\text {ads. }}^{\mathrm{o}}$ by the following equation:

$$
\mathrm{K}=\frac{1}{55.5} \exp \frac{-\Delta \mathrm{G}_{\mathrm{ads}}^{\mathrm{o}}}{\mathrm{RT}}
$$

where $\mathrm{R}$ is the universal gas constant and $\mathrm{T}$ is the absolute temperature.

Figs. 3 and 5 represent the Flory-Huggins adsorption isotherms for tellurium and palladium, respectively. The slope of the straight lines gives the $\mathrm{X}$ values, while the intercepts give the $\mathrm{K}$ values. On the other hand, Figs. 4 and 6 illustrate the kinetic model, which can be expressed by equation (3). The slopes of these straight lines give $(1 / y)$, and from the intercepts we get $\mathrm{K}$ values. 


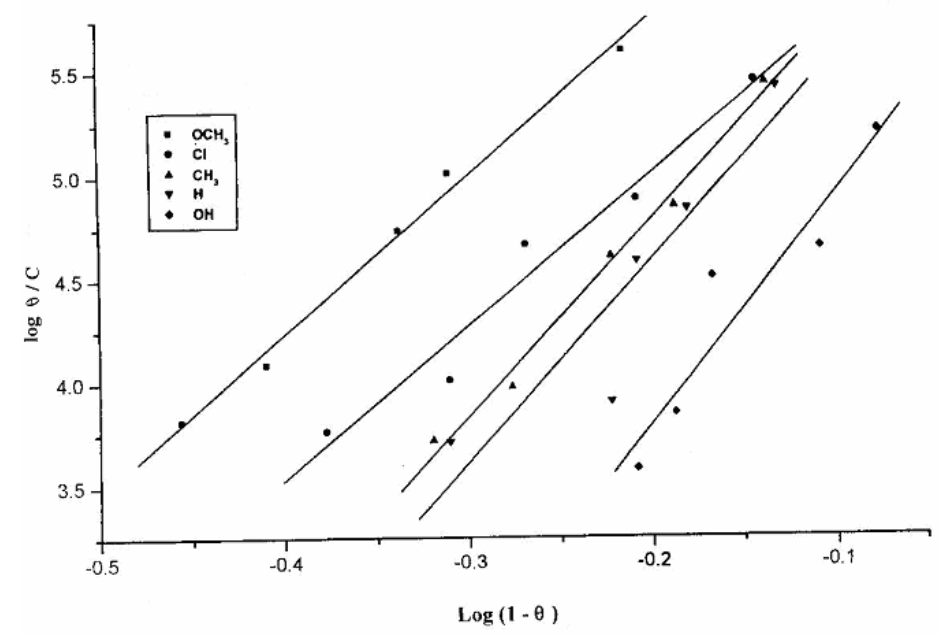

Figure 3. Curve fitting the corrosion data of Te in $0.5 \mathrm{M} \mathrm{HNO}_{3}$ in the presence of all inhibitors used to the Flory-Huggins isotherm at different concentrations.

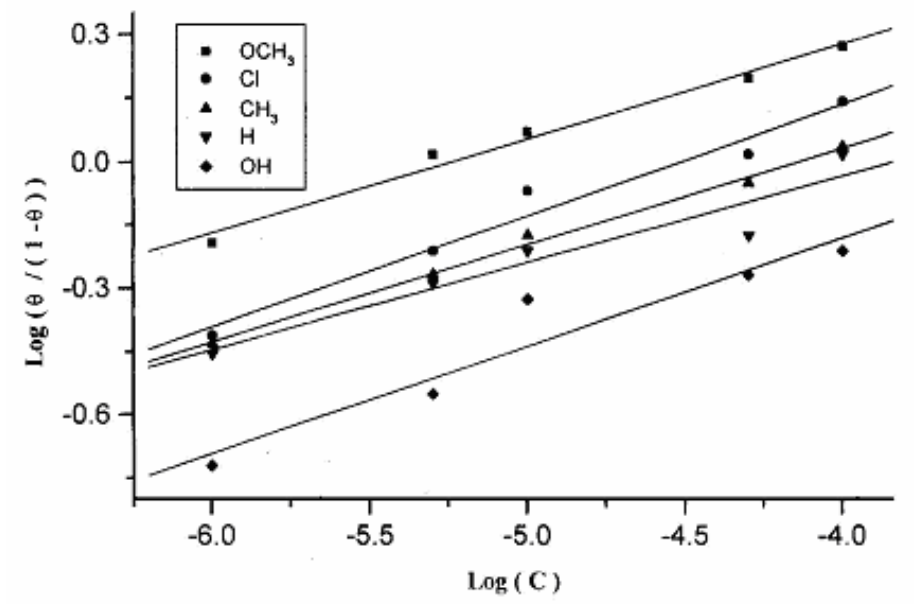

Figure 4. Curve fitting the corrosion data of Te in $0.5 \mathrm{M} \mathrm{HNO}_{3}$ in the presence of all inhibitors used to the kinetic model. 


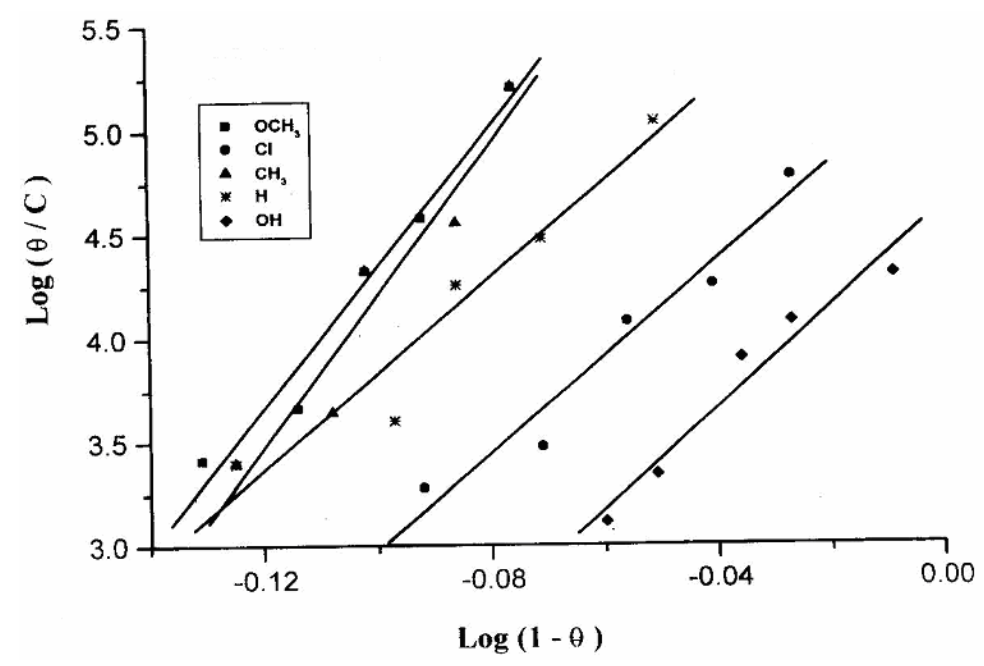

Figure 5. Curve fitting the corrosion data of $\mathrm{Pd}$ in $0.5 \mathrm{M} \mathrm{HNO}_{3}$ in the presence of all inhibitors used to the Flory-Huggins isotherm at different concentrations.

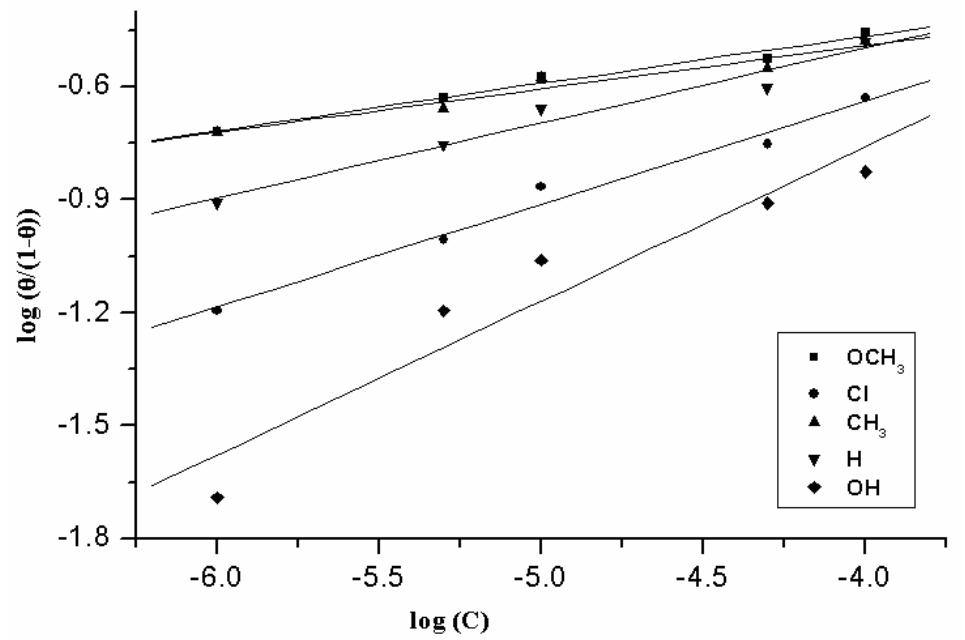

Figure 6. Curve fitting the corrosion data of $\mathrm{Pd}$ in $0.5 \mathrm{M} \mathrm{HNO}_{3}$ in the presence of all inhibitors used to the kinetic model.

The calculated values of $\mathrm{K}, \Delta \mathrm{G}_{\mathrm{ads}}^{\mathrm{o}}$ and $\mathrm{x}$ are given in Tables 3 and 4 for tellurium and palladium, respectively. Inspection of the data of these tables shows that the negative sign of $\Delta \mathrm{G}_{\mathrm{ads}}^{\mathrm{o}}$ indicates that the adsorption of 3-phenyl hydrazonoacetyl acetone derivatives on the electrodeposited tellurium and palladium surfaces is proceeding spontaneously and is accompanied by a highly-efficient adsorption. It is worth noting that the value of $\mathrm{x}$ is more than unity. This means that the given 
inhibitor molecules will occupy one active site. The values of $\Delta \mathrm{G}_{\text {ads }}^{\mathrm{o}}$ are nearly within the limits of 21-42 $\mathrm{KJ} \mathrm{mol}^{-1}$ which have been observed for the majority of organic inhibitors of various types in aqueous media [15].

Table 3. Inhibitor binding constants, free energy of binding, number of active sites and lateral interaction for compounds I, II, III, IV and V in case of Te.

\begin{tabular}{|c|c|c|c|c|c|c|}
\hline \multirow{2}{*}{ Compound } & \multicolumn{3}{|c|}{ Kinetic model } & \multicolumn{3}{c|}{ Flory-Huggins } \\
\cline { 2 - 7 } & $1 / \mathrm{y}$ & $\mathrm{K}$ & $\begin{array}{c}-\Delta \mathrm{G}_{\text {ads. }}^{\mathrm{o}} \\
(\mathrm{KJ} / \mathrm{mol})\end{array}$ & $\mathrm{X}$ & $\mathrm{K}$ & $-\Delta \mathrm{G}_{\text {ads. }}^{\mathrm{o}}$ \\
& & & $1 \mathrm{KJ} / \mathrm{mol})$ \\
\hline I & 4.5 & 14.5 & 16.9 & 7.6 & 7.3 & 15.1 \\
\hline II & 3.8 & 15.3 & 17.0 & 7.4 & 6.5 & 14.8 \\
\hline III & 4.4 & 8.8 & 15.6 & 9.5 & 10.7 & 14.9 \\
\hline IV & 4.9 & 6.1 & 14.7 & 9.8 & 6.5 & 14.8 \\
\hline V & 3.9 & 6.9 & 15.0 & 11.1 & 6.0 & 14.6 \\
\hline
\end{tabular}

\section{Effect of chemical composition of additives on tellurium and palladium} corrosion inhibition

The results recorded in Tables 5 and 6 indicate that the efficiency of tellurium and palladium corrosion inhibition as determined from protection efficiency varies with both the concentration and the type of additives used.

Table 4. Inhibitor binding constants, free energy of binding, number of active sites and lateral interaction for compounds I, II, III, IV and V in case of Pd.

\begin{tabular}{|c|c|c|c|c|c|c|}
\hline \multirow{2}{*}{ Compound } & \multicolumn{3}{|c|}{ Kinetic model } & \multicolumn{3}{c|}{ Flory-Huggins } \\
\cline { 2 - 7 } & $1 / \mathrm{y}$ & $\mathrm{K}$ & $\begin{array}{c}-\Delta \mathrm{G}_{\text {ads. }}^{\mathrm{o}} \\
(\mathrm{KJ} / \mathrm{mol})\end{array}$ & $\mathrm{X}$ & $\mathrm{K}$ & $\begin{array}{c}-\Delta \mathrm{G}_{\text {ads. }}^{\mathrm{o}} \\
(\mathrm{KJ} / \mathrm{mol})\end{array}$ \\
\hline I & 7.9 & 1.1 & 10.3 & 33.8 & 7.7 & 15.3 \\
\hline II & 3.7 & 2.8 & 12.7 & 23.3 & 5.3 & 14.3 \\
\hline III & 8.7 & 1.0 & 9.9 & 36.4 & 7.8 & 15.3 \\
\hline IV & 5.0 & 2.0 & 11.9 & 23.1 & 6.1 & 14.7 \\
\hline V & 2.4 & 7.5 & 15.2 & 24.4 & 4.6 & 14.0 \\
\hline
\end{tabular}

However, inhibition efficiency of additive compounds depends on many factors [7] which include the number of adsorption active centers in the molecules and 
their charge density, molecular size, mode of adsorption, heat of hydrogenation and formation of metallic complexes.

The obtained results indicate that the decrease in protection efficiency of the additives in nitric acid corrosion at all concentrations is in the order I $>$ II $>$ III $>$ IV $>$ V for tellurium and in the order I $>$ III $>$ IV $>$ II $>$ V for palladium.

Table 5. Protection efficiency of corrosion inhibition of tellurium by polarization for 3phenyl hydrazonoacetyl acetone derivatives.

\begin{tabular}{|c|c|c|c|c|c|}
\hline $\begin{array}{c}\text { Concentration of the } \\
\text { additive } \\
(\mathrm{M})\end{array}$ & \multicolumn{5}{|c|}{ \% Protection efficiency } \\
\cline { 2 - 6 } & I & II & III & IV & V \\
\hline $1 \times 10^{-6}$ & 40 & 28 & 28 & 26 & 15 \\
\hline $5 \times 10^{-6}$ & 51 & 35 & 35 & 34 & 22 \\
\hline $1 \times 10^{-5}$ & 55 & 48 & 41 & 35 & 31 \\
\hline $5 \times 10^{-5}$ & 60 & 53 & 46 & 40 & 34 \\
\hline $1 \times 10^{-4}$ & 64 & 58 & 52 & 51 & 37 \\
\hline
\end{tabular}

In the present case variation in structure of the inhibitor molecules takes place through para-substituents of the phenyl ring in the hydrazone part. Inhibition efficiency differences would probably originate from this part of the molecules while the acetyl acetone moiety remains constant. Polarization measurements indicated that the compounds act as cathodic inhibitors probably through the protonated nitrogens in the molecules. Skeletal representation of the mode of adsorption of the inhibitor molecules shown in Fig. 7 strongly suggests the nitrogen atom attached to the phenyl ring as the seat of adsorption and its basicity would be affected by the p-substituents in the ring.

Table 6. Protection efficiency of corrosion inhibition of palladium by polarization for 3phenyl hydrazonoacetyl acetone derivatives.

\begin{tabular}{|c|c|c|c|c|c|}
\hline $\begin{array}{c}\text { Concentration of the } \\
\text { additive } \\
(\mathrm{M})\end{array}$ & I & II & III & IV & V \\
\cline { 2 - 6 } & 16 & 15 & 11 & 6 & 2 \\
\hline $1 \times 10^{-6}$ & 19 & 18 & 15 & 9 & 5 \\
\hline $5 \times 10^{-6}$ & 21 & 20 & 18 & 12 & 8 \\
\hline $1 \times 10^{-5}$ & 29 & 22 & 20 & 15 & 11 \\
\hline $5 \times 10^{-5}$ & 26 & 25 & 25 & 19 & 13 \\
\hline $1 \times 10^{-4}$ & &
\end{tabular}




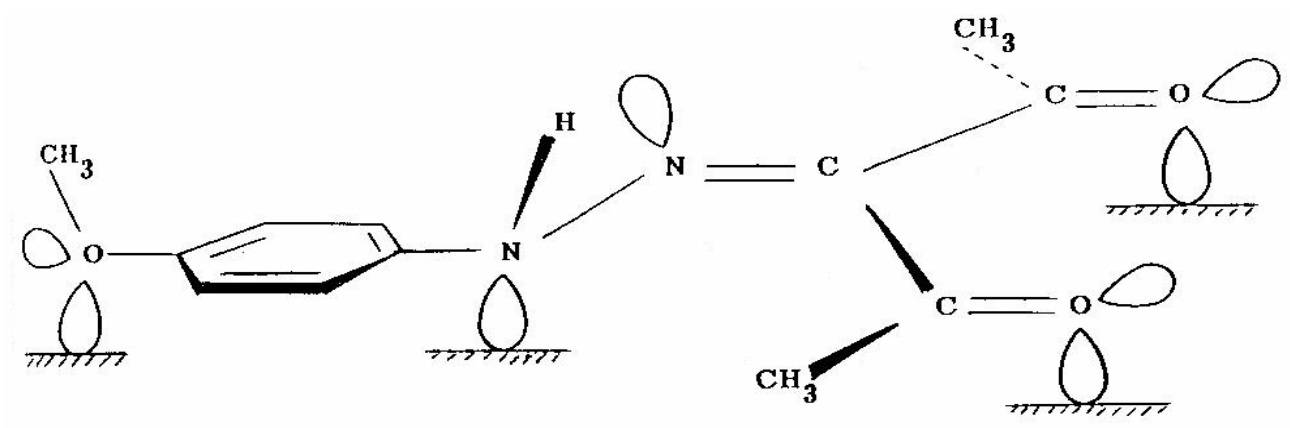

Figure 7. Skeletal representation of the mode of adsorption of inhibitored.

Most para-substituents undergo resonance with the reaction center. When resonance is possible across the aromatic system between substituent and functional center, any change in this interaction between initial and transition states of a process produces a resonance effect, i.e., the substituent effect on rate is a composite of polar and resonance effects. However, the effect will be specific for the type of substituent, functional group and reaction involved. Based on Hammett's polar substituent constants, $\sigma$, charge density at the nitrogen atom would decrease in the order: $\mathrm{OH}>\mathrm{OCH}_{3}>\mathrm{CH}_{3}>\mathrm{H}>\mathrm{Cl}$. A comparable order of decreased corrosion inhibition efficiency could be expected for the p-substituted additives if polar effects are only operating. However, Hammett [16] pointed out that a substantial resonance contribution to the net electron releasing effect exists for $\mathrm{p}-\mathrm{OCH}_{3}$ group and it is thus not surprising that (I) come on top of this series of inhibitors. The p-chloro derivative (II) follows next and intrudes between electron releasing groups despite the electrophilic character of the $\mathrm{Cl}$ substituent. Here, a mesomeric effect $(+\mathrm{M})$ involving electron pairs on $\mathrm{Cl}$ can operate in opposite direction to the - I effect and the overall mechanism constitutes electron release which maintains sufficient electron charge density on the nitrogen atom. A similar effect was noted in other cases [17-18]. Also, increased inhibition could be due in part to increased molecular weight (size) of $\mathrm{Cl}$ over that of $-\mathrm{OH}$, $-\mathrm{CH}_{3}$ and $\mathrm{H}$ substituents. The $\mathrm{OH}$-substituted compound (V) is the least effective 
inhibitor among the compounds under investigation due to the formation of soluble tellurium and palladium complexes that are not integrated in the oxide layer, thus weakening it. A phenol gives a colouring reaction with ferric chloride due to the formation of an iron salt. A similar reaction probably takes place with tellurium and palladium.

In conclusion, for all compounds the magnitude of inhibition efficiency is higher for tellurium than for palladium. This may be due to the different natures of the two metals and also to the different ability of the two metals to adsorb hydrogen. Ordinarily the corrosion process is much more retarded by polarization of the cathode. Hence, corrosion will be intensified by all factors hindering cathodic polarization and causing depolarization of the cathode. Hydrogen depolarization would be expected to be higher for palladium in presence of the inhibitors owing to its higher ability to adsorb hydrogen. For this reason the additives are less efficient inhibitors for palladium in nitric acid corrosion. The difference in the order of inhibition efficiency of the 3-phenyl hydrazonoacetyl acetone derivatives noted for palladium may similarly be interpreted. The p-chloro derivative (II) facilitates by its $+\mathrm{M}$ effect cathodic depolarization of palladium and consequently descends in the order of inhibition efficiency.

\section{References}

1. A. El-Sayed, J. Appl. Electrochem. 27 (1997) 193.

2. G. Schmitt, Br. Corros. J. 19 (1984) 165.

3. M.N. Moussa, F.I. Taha, M.M. Gouda and G.M. Singab, Corros. Sci. 16 (1976) 379 .

4. A.O. Baglaff, S.A. Al-Hamood and M.N. Moussa, Corros. Sci. (1980).

5. S.M. Hassan, M.N. Moussa, F.I. Taha and A.S. Fouda, Corros. Sci. 21 (1981) 439 .

6. A.S. Fouda, M.N. Moussa and H.A. Mostafa, Korrosion (Dresden), 18(1) (1987) 28.

7. A.S. Fouda, M.N. Moussa, F.I. Taha and A.I. Elneanaa, Corros. Sci. 26 (1986) 719. 
8 A.S. Fouda, H.M. Abo El-Nader and M.N. Moussa, Acta Chimica Hung. 124(4) (1987) 581.

9. A.M. El-Baz, Ph.D. Thesis, Mansoura Univ., (1987), Egypt.

10. A.A. Fadda, M.M. Yousef, Y.M. Darwish and A.M. El-Housin, Ind. J. Texst. Res. 11 (1986) 44.

11. A.S. Fouda, H.A. Mostafa, M.N. Moussa and S.M. El-Masry, J. Radioanal. Nucl. Chem., Letters 118(1) (1987) 45.

12. S.M. El-Masry, Ph.D. Thesis, El-Mansoura Univ., Egypt (1988).

13. B.B. Damaskin "Adsorption of Organic Compounds on Electrodes" p. 221, 263, Plenum Press, N.Y. (1971).

14. A.A. El-Awady, B.A. Abd El-Naby and S.G. Aziz, J. Electrochem. Soc. 139(8) (1992) 2149.

15. W.W. Damaskin and O.A. Pietrij, Elektrodach. Moskwa (1968).

16. L.P. Hammett, "Physical Organic Chemistry" P- 196, McGraw-Hill Book Co., N.Y. (1940).

17. A.K. Mohamed, Ph.D. Thesis, Mansoura University, Egypt (1986).

18. B.A. Abd El-Naby, A. El-Tokhy, M. El-Gamel and F. Mahgoob, Surf. Coat. Technol. 27(4) (1986) 325. 